$2-1-2005$

\title{
Reconsidering the Commission's Treatment of Tribal Courts
}

Kevin Washburn

University of New Mexico - School of Law

Follow this and additional works at: https://digitalrepository.unm.edu/law_facultyscholarship

Part of the Indian and Aboriginal Law Commons

\section{Recommended Citation}

Kevin Washburn, Reconsidering the Commission's Treatment of Tribal Courts, 17 Federal Sentencing Reporter 209 (2005).

Available at: https://digitalrepository.unm.edu/law_facultyscholarship/502

This Article is brought to you for free and open access by the UNM School of Law at UNM Digital Repository. It has been accepted for inclusion in Faculty Scholarship by an authorized administrator of UNM Digital Repository. For more information, please contact amywinter@unm.edu, Isloane@salud.unm.edu,sarahrk@unm.edu.

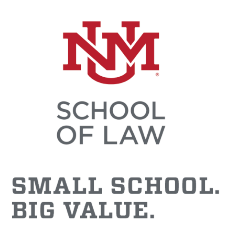

BIG VALUE. 


\section{Reconsidering the Commission's Treatment of Tribal Courts}

\section{Introduction}

Since the U.S. Sentencing Commission first enacted the federal Sentencing Guidelines, the Guidelines have treated tribal courts in a manner that is impossible to reconcile with other modern federal policies of respect for tribal self-determination and self-governance. In refusing to count tribal convictions for purposes of routine calculation of criminal history, the Commission has disrespected tribal courts. The Commission's tribal courts policy is anachronistic and out of step with modern efforts to support tribal courts.' The Commission should amend the guidelines to reflect the principle that misdemeanor convictions from tribal courts are entitled to the same level of respect as misdemeanor convictions from state, county, and municipal courts.

\section{The Status of Tribal Courts in Federal Sentencing} In making criminal history one of the two key determinants, the Commission gave enormous weight to a defendant's past criminal conduct, reflecting the notion that recidivism was a very important ingredient of the Commission's sentencing policy.

\section{A. Importance of Past Convictions in Guideline Sentencing}

The Commission determined that municipal, county and state court sentences would be counted in the criminal history calculation ${ }^{2}$ and that sentences from tribal courts and foreign courts would be considered only in extraordinary circumstances. Thus, under the Guidelines as enacted and as applied today, a tribal or foreign court sentence is not routinely counted in criminal history computations, ${ }^{3}$ but constitutes a "favored" basis for upward departure. ${ }^{4}$

\section{B. Tribal Courts and Foreign Courts}

At first glance, one might conclude that the Commission was merely seeking to be respectful of tribal sovereignty in treating Indian tribes akin to foreign nations. Although the authority of tribal courts, like the authority of foreign courts, arises from a source of sovereignty that is foreign to the states and the United States, tribal and foreign courts ought not to be likened to one another. Chief Justice John Marshall famously held that tribes are not foreign nations, and are more correctly denominated

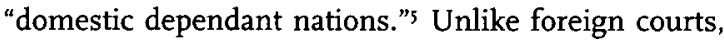
tribal courts have an integral role to play in the criminal justice regime within the boundaries of the United States. Offenders travel to and from Indian reservations far more freely and more often than between the United States and foreign nations. Moreover, it is far easier for federal courts to obtain cooperation from tribal courts that lie wholly within the United States (and the territorial reach of federal courts). ${ }^{6}$

Since only tribal courts have jurisdiction over certain misdemeanor offenses on Indian reservations, the structure of the federal Indian country criminal justice system reflects, in effect, a partnership between the federal government and the various tribal governments. The role of tribal courts is essential to the maintenance of public safety and public order in these communities. In contrast, foreign courts lack any important role in the domestic life of the United States. Thus, tribal courts and foreign courts are quite different.

\section{Tribal Courts and State Courts}

An obvious alternative to treating tribal courts like foreign courts is treating tribal courts like state courts. Though the Commission did not spend a lot of time deliberating as to whether to count state court sentences in computing federal sentences, 7 it likely believed state sentences to be trustworthy because states are bound to provide substantially the same procedural protections to criminal defendants that federal courts must provide.

This argument, while true, fails to distinguish state courts in any meaningful respect from tribal courts; both must provide substantially the same federal protections to criminal defendants. Indeed, the history is illuminating on this question. As a practical matter, the Supreme Court held during the nineteenth century that the federal Bill of Rights does not apply of its own force to states or tribes. ${ }^{8}$ During the decades-long incorporation controversy, the Supreme Court came to decide that the Fourteenth Amendment incorporated most of the federal criminal procedural protections. The peak of this activity occurred during the Warren Court era. As the interminable process of federal litigation in the Supreme Court gradually began to impose more and more of the federal criminal procedural protections on state

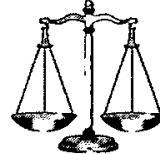

KEVIN WASHBURN

Associate Professor, University of Minnesota Law School 
courts, in 1968 Congress enacted the Indian Civil Rights Act. ${ }^{9}$

In one fell swoop, tribes were required to provide most of the criminal procedural protections found in the Bill of Rights. ${ }^{\circ}$ Long after Congress enacted the Indian Civil Rights Act, states were still aggressively litigating against the notion that the federal Constitution required them to provide certain rights. For example, when the Indian Civil Rights Act was enacted, the Supreme Court had not yet rendered its decision in Duncan v. Louisiana, ${ }^{\text {II }}$ holding that the Fourteenth Amendment incorporated the Sixth Amendment right to a jury trial. Likewise, the Court had not yet rendered its decision in Benton v. Maryland, ${ }^{, 2}$ holding that the Fourteenth Amendment incorporates the Fifth Amendment's prohibition of double jeopardy which prevents a state from prosecuting a defendant twice for the same offense. Finally, the Court had not yet rendered its decision in Schilb v. Kuebel, ${ }^{13}$ in which the Court made explicit its assumption that the Fourteenth Amendment incorporated the Eighth Amendment's prohibition on excessive bail.

Thanks to these decisions, it was not long after enactment of the Indian Civil Rights Act that the Supreme Court ordered state courts to meet the same high standards of procedural protection already required of tribal courts. But the timing is noteworthy and it bears emphasis: tribal courts were required by Congress to provide numerous protections to criminal defendants before states recognized such requirements.

Today, the nature of the due process protections in state and tribal courts is virtually identical. Though tribal courts and state courts traveled different paths, all must now provide most of the substantive protections set forth in the Bill of Rights.

Empirical evidence suggests that tribal courts routinely hear the same kinds of misdemeanor cases that state courts handle. In the i999 Means v. Navajo Nation decision, ${ }^{14}$ the Navajo Nation Supreme Court noted that its lower courts adjudicated 27,602 cases in the previous fiscal year. Of these cases, more than twenty percent were adjudications of the offense of driving while intoxicated and more than twenty percent were adjudications of crimes against persons, such as simple assault. Based on these statistics, the court summarized the criminal work of the lower Navajo courts as "addressing the serious criminal and social problems of drunk driving, assaults and batteries (including aggravated assault and battery with deadly weapons), sex offenses against children, disorderly conduct, and public intoxication." Thus, tribal courts seem to have caseloads similar to misdemeanor state court dockets.

Most tribal judicial systems are structured very much like the state and federal court systems; state and federal law heavily influence tribal court procedures. Some tribal courts "operate as nearly exact replicas of state courts." is Commentators have occasionally challenged the quality of tribal courts, but the same kinds of criticisms are frequently raised against rural state courts ${ }^{16}$ and it has not been argued that sentences from such courts should be discounted. In sum, it is difficult to find compelling practical or legal differences between state and tribal courts.

Since courts serve as the primary instruments of criminal justice for communities, the message that this conveys is that states and cities are entitled to respect, but tribal communities are not. Such an approach raises serious questions.

\section{The Limited Right to Counsel in Tribal Court}

Despite all the similarities, there is one key distinction between tribal courts and state courts. Although the Indian Civil Rights Act insures that defendants have a right to counsel to assist in the defense of criminal charges in tribal courts, Congress pointedly refused to impose on tribal governments the principle first announced in Johnson v. Zerbst, ${ }^{17}$ and applied to the states in Gideon v. Wainwright, ${ }^{t 8}$ that such counsel must be provided at government expense. ${ }^{19}$ Accordingly, unlike state courts, tribal courts are under no federal requirement to provide indigent defense counsel or public defenders for misdemeanor defendants. ${ }^{20}$

Those concerned with the quality of justice in tribal courts frequently cite this fact in attacking tribal courts. ${ }^{2 x}$ While this might be considered a serious flaw by those concerned with the rights of criminal defendants in tribal courts (and this author agrees that such criticism is legitimate), such a concern should not prohibit the counting of tribal court sentences from the vast majority of tribal courts. First, a substantial number of tribal governments now exceed the bare requirements of the Indian Civil Rights Act and provide indigent counsel to tribal defendants. ${ }^{22}$ In some tribal courts, provision of indigent counsel is a matter of court rules and local practice. In others, it is mandated by the tribal code. ${ }^{23}$ In any event, because many tribes routinely provide attorneys to indigent defendants, lack of counsel is not a legitimate basis for refusing to count the sentences from those tribal courts. Second, there are simple ways to differentiate between those tribal convictions in which such counsel was provided and those in which this was not the case. Thus, it is difficult to defend the notion that tribal courts ought to be treated more like foreign courts than like state courts.

\section{The Status of Tribal Courts in Federal Law, Policy and Criminal Justice}

In the last thirty years, the United States has broadly and comprehensively embraced a new official policy that favors federal support of tribal self-governance. Since President Richard Nixon first outlined a detailed policy in favor of tribal self-determination in 1970, every American President has voiced strong support for the notion that the federal government should encourage, support, and even honor tribal governmental institutions. In keeping with 
presidential directives, the Department of Justice issued an official policy on "Indian Sovereignty and Governmentto-Government Relations with Indian Tribes" indicating that the Department "is committed to strengthening and assisting Indian tribal governments in their development and to promote tribal self-governance." ${ }^{24}$ Numerous Executive Branch and independent agencies have followed suit.

Following the lead of the Executive Branch, Congress has adopted the tribal self-determination policy as its own by creating or amending programs throughout the federal government to accommodate and embrace tribal selfdetermination. ${ }^{25}$ Congress has singled out tribal courts and has repeatedly expressed its confidence in, and support of, these growing institutions. ${ }^{26}$ Among other developments, Congress has required all courts in the United States to grant full faith and credit to certain kinds of tribal court judgments: ${ }^{27}$

Nowhere is the federal government's respect for tribal courts more visible than in the federal courts. In 1985 , in National Farmers Union Insurance Co. v. Crow Tribe, ${ }^{28}$ the Supreme Court adopted a rule requiring exhaustion of tribal court review of federal questions regarding the scope of tribal jurisdiction, making tribal courts, if not master of their own universe then, at least, gatekeepers to the federal courts for questions of their own jurisdiction under federal law. In light of this case and many others, tribal courts "have an increasingly important role to play in the administration of the laws of our nation," in the words of Justice O'Connor. ${ }^{29}$

\section{A. Tribal Courts and Tribal Criminal Justice}

Though the federal Indian country criminal justice regime has been described as complex, ${ }^{30}$ tribal courts play a definitive role in it. They do not possess jurisdiction over non-Indians, ${ }^{31}$ but tribal courts do possess jurisdiction over crimes committed by tribal members ${ }^{32}$ and other Indians. ${ }^{33}$ Indeed, federal and state courts generally lack jurisdiction over what is likely the largest category of crime in Indian country, misdemeanor offenses committed by one Indian against another. Tribal court jurisdiction is therefore generally exclusive in this respect. ${ }^{34}$ The fact that Congress has left the tribes with exclusive jurisdiction over misdemeanor offenses is evidence that it expects tribal courts to exercise misdemeanor jurisdiction. ${ }^{35}$ If tribal prosecutors and tribal courts do not act, these offenses, such as the 27,602 misdemeanor offenses on the Navajo reservation in a recent year, will go unpunished,,$^{36}$ creating de facto prosecution-free zones.

Congress indicated in 2000 that "the rate of violent crimes committed in Indian country is approximately twice the rate of violent crime committed in the United States as a whole[.]" 37 The Department of Justice found that Native Americans experience violent crime at the rate of about one violent crime victim in every eight residents. This compares to a rate of one in sixteen for African Americans and one in twenty for whites. ${ }^{38}$ In such a high crime environment, many would agree that one of the most important components of crime control is insuring that misdemeanor offenses are addressed. ${ }^{39}$

\section{B. Federal Courts and Tribal Criminal Justice}

Unlike misdemeanors, the federal government exclusively prosecutes approximately two dozen offenses, characterized in federal law as the "major crimes," when committed on a reservation..$^{\circ}$ This jurisdictional scheme creates what is, in effect, a partnership with federal courts handling the major crimes (felonies) and the tribal courts handling other offenses (misdemeanors). ${ }^{41}$

Congress and the Supreme Court have expressed their recognition of the increasing importance of tribal courts in our federal statutory and common law criminal justice scheme. The interconnectedness of tribal courts with federal criminal justice and federal courts with tribal criminal justice suggests an unjustifiable asymmetry in the Guidelines' refusal to count tribal court convictions in determining an offender's criminal history score. With this background, let us now evaluate the policy implications of the Commission's treatment of tribal court convictions.

\section{Practical and Theoretical Problems with the \\ Commission's Current Policy}

Most of the key institutions of the federal government have agreed that federal policymakers should shift decision making to tribal governments where possible, give respect to tribal institutions, and consult with and seek the guidance of tribal governments on matters that peculiarly affect Indian people. In light of its policy on tribal courts, the Commission is out of step with virtually every other department of the U.S. Government. Its policy is also inconsistent with the theoretical underpinnings of its sentencing regime.

\section{A. Inconsistency with Underlying Sentencing Policy} The Guidelines were created to reduce disparity in federal sentencing and to insure that each defendant is sentenced with due regard to his culpability as measured by the current offense and previous offenses. ${ }^{4^{2}}$ The current policy simply fails to meet the purposes of accuracy and fairness that are among the stated bases for the Guidelines. A defendant with a lengthy tribal criminal history who lacks any state or federal convictions will be routinely treated as a first-time offender by the federal courts and hence receive a shorter sentence than his criminal history score might otherwise justify. While the Commission declined to adopt a single overarching theory of the purpose of sentencing, ${ }^{43}$ it drew upon retributivism as well as utilitarian theories of deterrence, incapacitation and rehabilitation. ${ }^{44}$ According to the Commission's rationale for using criminal history as a key basis of sentencing, "[a] defendant with a record or prior criminal behavior is more culpable than a first offender and thus deserving of greater punishment." 45 
Such a justification is impossible to square with the Commission's failure to count tribal court sentences.

Similarly, the Commission has justified the use of criminal history by explaining that one of the best predictors of future criminal conduct is past criminal conduct. It has argued, therefore, that use of criminal history is an important means of crime control through incapacitation of likely future offenders. ${ }^{46}$ If the retributivist theory, or any of the utilitarian theories, is legitimate, the high crime rate involving Indians would seem to justify the use of tribal criminal records. Thus, the Commission's policy of ignoring tribal court sentences is impossible to square with it own stated policies as to the goals of sentencing.

\section{B. The Broader Context}

One way to evaluate the Commission's policy is to look at the actions of the federal courts. If the activity of federal judges in using trial court records as a basis for upward departure is any guide, many of the judges who apply the Guidelines seem not to share the Commission's lack of respect for tribal court sentences. Despite the general rarity of upward departures, federal judges have often used the existence of a lengthy tribal criminal history to justify an upward departure in Indian country cases. ${ }^{47}$

Likewise, federal district court judges often use tribal convictions as predicates for the transfer of juvenile offenders to adult status. ${ }^{4^{8}}$ Because the facts of such cases usually justify discretionary transfer, the appeals courts have not had to reach the question as to whether the tribal convictions are predicates for mandatory transfers. In any event, federal judges have found the records created by tribal courts to be trustworthy, despite the serious ramifications for youthful defendants.

Even state courts and legislatures, though they have long competed with tribal courts for jurisdiction, ${ }^{49}$ have begun to embrace the notion that tribal court dispositions are worthy of reliance in state criminal proceedings and for other purposes. At least five states, including Michigan, Montana, New Mexico, Wisconsin, and Wyoming, allow prior tribal court convictions to serve as predicates for enhanced charges for subsequent state prosecutions for driving under the influence of alcohol..$^{\circ 0}$ At least nine states honor tribal court sentences in the context of sex offender registries. ${ }^{51}$ Still other states rely on tribal convictions in a variety of other contexts, such as treating them as predicate offenses for enhancement of sentences in domestic violence prosecutions ${ }^{52}$ and even computing criminal history for sentencing purposes. ${ }^{53}$ In sum, in a number of substantive areas, state courts trust tribal court convictions.

Thus, in addition to being out of step with federal policy, the Commission's position on tribal courts seems anachronistic in comparison to the respect that state legislatures and courts are beginning to give tribal court criminal convictions.

\section{Harmonizing Federal Indian Country Sentencing with Current Federal Indian Policy and the Commission's Sentencing Theory}

The Commission should recognize that tribal courts are substantially more like state courts than foreign courts and should accord tribal courts the same respect that they receive from the rest of the federal government.

One obvious way to accomplish this is simply to eliminate the Guidelines provision indicating that "sentences resulting from tribal court sentences are not to be counted." 54 Such an amendment, which would change the default rule to one of routine consideration of tribal court sentences, would both improve the accuracy of the criminal history for any individual defendant and correct the current policy's apparent lack of respect for tribal courts.

As for the concern about the lack of a federal requirement for provision of indigent defense counsel in tribal courts, the Commission could choose to consider only those tribal convictions and sentences resulting in imprisonment in which a defendant was represented by counsel. Such a determination may not be required under federal law but is nevertheless justifiable given the importance of the institutional role of defense counsel in the American criminal justice system. Such an approach would address legitimate federal concerns in a manner that is respectful to tribal courts. Moreover, it might encourage tribes to provide indigent counsel.

However, from the standpoint of federal Indian policy, a unilateral directive from the federal government as to how tribal sentences will be used in federal courts may not be the ideal approach for furthering tribal selfgovernance. Instead, an alternative approach, consistent with the notion of the United States' government-togovernment relationship with Indian tribes, might give individual tribal governments the ultimate power to determine whether their tribal convictions should be used in federal sentencing. In other words, the Commission should modify the Guidelines to create the default rule of respect for tribal court sentences as outlined above, but the Commission could further recognize a tribal government's right to "opt-out" of the scheme by indicating that their sentences should not be considered in federal sentencing. Such a policy would make the tribe the ultimate decision maker.

The "tribal option" approach can be criticized on the grounds that it would less fully address the inaccuracies in sentencing caused by the failure to count tribal convictions. However, reasonable accommodations for tribal sovereignty and tribal self-governance should trump general sentencing policy, particularly when the case is federal only because it arises in Indian country and Indian defendants are being sentenced.

One potential objection to the tribal option approach is that, on its face, if seems to give tribal governments greater control over federal consideration of tribal sentences than states have over federal consideration of state sentences. 
The Guidelines do not allow states a parallel "opt out" option. Tribal governments, however, have a fundamentally different relationship with the United States than states have. Constitutional limits prevent the federal government from displacing state governments for purposes of routine felony prosecutions. ${ }^{55}$ Congress has, however, unilaterally and explicitly authorized the exercise of power on Indian reservations that it could never exercise outside the federal reservations. ${ }^{56}$ Thus, the federal government, with the blessing of the Supreme Court, has unilaterally limited the criminal justice authority of tribal governments to misdemeanors. ${ }^{57}$ Given the unilateral nature of this federal action, tribes ought to have some power to moderate how much they wish to participate in a system that was, after all, forced upon them. Precedent for such unique treatment of tribes is well established; Congress recognized that tribes ought to be treated differently than states in 1994 when it created a tribal option as to the federal death penalty, but offered no such option to the states..$^{8}$

\section{Conclusion}

The Commission stands as perhaps the only important federal governmental agency with an official policy of disrespect for tribal courts. By ignoring tribal sentences, the Guidelines have institutionalized a policy of disrespect for tribal courts and the important work that they do addressing public safety issues in tribal communities. In the light of the prevailing norm of tribal self-governance in federal Indian policy and the underlying Guideline policies of retributivism and incapacitation of recidivists, the Commission's decision not to credit the legitimate work of tribal courts in adjudicating misdemeanor sentences is indefensible. The Commission should reconsider Section 4AI.2(i) which prevents tribal court sentences from being used in the routine calculation of criminal histories. The Commission should change its tribal courts policy and recognize that the sentences of tribal courts are entitled to the same respect as state court sentences in the federal sentencing regime.

\section{Notes}

1 The federal Indian country criminal justice regime is generally codified at 18 U.S.C. $\S \S 1151-1153$ (2001). For commentary describing and critiquing the current state of sentencing for Indian country offenses, see Charles B. Kornmann, Injustices: Applying the Sentencing Guidelines and Other Federal Mandates in Indian Country, 13 FED. SENT. REP. 71 (2000); Jon M. Sands, Indian Crimes and Federal Courts, 11 Fed. Sent. Rep. 153 (1998); Jon M. Sands, Departure Reform and Indian Crimes, Reading the Commission's Staff Paper With "Reservations," 9 FEd. SENT. ReP. 1 (1996).

2 See U.S.S.G. $\S \S 4 A 1.2(c)(1)$ (noting that local ordinance violations are counted if they are also criminal offenses under state law), 4A1.2 Application Note 12.

3 U.S.S.G. $\$ \$ 4 A 1.2(\mathrm{i})$ (tribal courts), $4 \mathrm{Al} .2(\mathrm{~h})$ (foreign courts)

4 See U.S.S.G. § 4A1.3(a); United States v. Drapeau, 110 F.3d 618 (8th Cir. 1997).

5 Cherokee Nation v. Georgia. 30 U.S. (5 Pet.) 1 (1831).
6 See, e.g., In re Long Visitor, 523 F.2d 443, 446 (8th Cir. 1975); United States v. Velarde, 40 F. Supp.2d 1314 (D.N.M. 1998); United States v. Boggs, 493 F. Supp. 1050, 1052-53 (D. Mont. 1980).

7 The Commission simply assumed that state court sentences would be counted in criminal history calculations consistent with past practice. See, e.g., U.S. SENTENCING COMM'N, SUPPLEMENTARY REPORT ON THE INITIAL SENTENCING GUIDELINES AND Policy Statements 41 \& n.67 (Jun. 18, 1987) [hereinafter U.S. Sentencing Commission, SuPPLEMENTARY RePORT].

8 Barron v. Baltimore, 32 U.S. (7 Pet.) 243 (1833) (states); Talton v. Mayes, 163 U.S. 376 (1896) (tribes).

9 Pub. L. No. 90.284, 82 Stat. 77 (1968), now codified at 25 U.S.C. $\$ \$ 1301-03$.

10 These included the Fourth Amendment's warrant requirements and the proscription against unreasonable searches and seizures, the Fifth Amendment's prohibition on double jeopardy, compelled self-incrimination, and deprivation of life, liberty, or property without due process, the Sixth Amendment's right to notice, a speedy and public trial, the right to confront witnesses, the right to compulsory process, and the right to counsel, the Eighth Amendment's proscriptions on excessive bail, excessive fines, or cruel and unusual punishment and even the Fourteenth Amendment's requirement of equal protection. See generally 25 U.S.C. $\S 1302$. But see discussion infra and accompanying text (noting the Act's lack of provision for indigent defense counsel).

$11 \quad 391$ U.S. 145 (1968).

12395 U.S. 784 (1969).

$13 \quad 404$ U.S. 357 (1971).

14 Russell Means v. District Court-Chinfe Judicial District, 26 INDIAN L. RPTR. 6083 (Navajo 1999).

15 Nell Jessup Newton, Tribal Court Praxis, a Year in the Life of Twenty Indian Tribal Courts, 22 AM. INDIAN L. Rev. 285, 287, 311 (1998). See also Oliphant v. Suquamish Indian Tribe, 435 U.S. 191, 211-12 (1978) (noting that "some Indian tribal court systems have become increasingly sophisticated and resemble in many respects their state counterparts.")

16 See, e.g., Debra Lynn Bassett, Ruralism, 88 lowa L. Rev. 273, $324 \& n .220$ (2003) ("rural [state] judges are seen as intellectually inferior to urban [state] judges").

17304 U.S. 458 (1938).

$18 \quad 372$ U.S. 335 (1963).

19 See 25 U.S.C. $\S 1302(6)$ (prohibiting tribes from denying "any person in a criminal proceeding the right...at his own expense to have the assistance of counsel for his defense") (emphasis added.)

20 This requirement is somewhat offset by a provision that makes tribal courts safer places for a defendant than state courts. Tribal courts must provide a jury trial to a misdemeanor defendant who is subject to any term of imprisonment. 25 U.S.C. $\S 1302(10)$. The federal right to a jury trial in state court is not so broad. See Duncan v. Louisiana, 391 U.S. at 159-61.

21 See, e.g., Note, The Right to Counsel in Native American Tribal Courts: Tribal Sovereignty and Congressional Control, $31 \mathrm{AM}$. CRIM. L. REV. 1279 (1994).

${ }_{22}$ Id. at $1297 \& \mathrm{n} .95$ (stating that "many of the more developed tribal court systems do attempt to provide counsel for criminal defendants").

23 See, e.g., Confederated Salish \& Kootenai Tribe Laws Codified, $\S \S 1 \cdot 2 \cdot 401(1)$ and (2).

24 Department of Justice Policy on Indian Sovereignty and Government-to-Government Relations with Indian Tribes (Jun. 1, 1995), available at http://www.usdoj.gov/otj/ sovtrb.htm. 
25 See Indian Self-Determination Act of 1975, 25 U.S.C. $\S 450 a-b$ (2002); see also Tribal Self-Governance Act of 1991, Pub. L. No. 102-84, 105 Stat. 1278 (amending portions of the Indian Self-Determination Act of 1975, 25 U.S.C. $\S \S 450-450 n$ ).

26 Congress has strongly expressed the view that tribal courts are worthy of respect and encouragement. See Tribal Justice Act, Pub. L. No. 103.176, § 2, 107 Stat. 2004 (1993) (codified at 25 U.S.C. § 3601(5)) (indicating that "triba! justice systems are an essential part of tribal governments"); Pub. L. No. 103-176, 107 Stat. 2004 (codified at 25 U.S.C. $\S \S 3611-14,3621 \mathrm{~b}$ ); Indian Tribal Justice Technical and Legal Assistance Act, Pub. L. No. 106-559, 114 Stat. 2778 (codified at 25 U.S.C. $\S 3651$ ) (also finding that "tribal justice systems are an essential part of tribal governments").

27 See, e.g., Violence Against Women Act, Pub. L. No. 103.322, Title IV, $\S 40221$ a, 108 Stat. 1930 (1994) (codified at 18 U.S.C. $\S 2265)$. See also Indian Child Welfare Act, 25 U.S.C. $\S 1911(\mathrm{~d})$.

$28 \quad 471$ U.S. 845 (1985).

29 Hon. Sandra Day O'Connor, Lessons from the Third Sovereign: Indian Tribal Courts, 33 TULSA L.J. 1, 6 (1997).

30 See, e.g., Robert N. Clinton, Criminal Jurisdiction Over Indian Lands: A Journey Through a Jurisdictional Maze, 18 ARIz. L. Rev. 503 (1976).

31 Oliphant v. Suquamish Indian Tribe, 435 U.S. 191 (1978).

32 United States v. Wheeler, 435 U.S. 313 (1978).

33 See 25 U.S.C. $\S 1301(2)$ and United States v. Lara, 541 U.S. 193 (2004).

${ }_{34}$ The United States has jurisdiction over only one misdemeanor offense involving Indians. See Major Crimes Act, 18 U.S.C. § 1153.

${ }_{35}$ Some would disagree with the characterization of tribal criminal jurisdiction as limited to misdemeanors by noting that tribes may, for example, prosecute even serious offenses such as murder. A tribe may indeed have the authority to prosecute one of its members for murder, but federal law limits the tribal sentence to one year. 25 U.S.C. $\S 1302(7)$. Because federal law classifies crimes by reference to the maximum term of imprisonment authorized for the crime, and explicitly defines a crime punishable by one year or less of imprisonment as a misdemeanor (see 18 U.S.C. $\S 3559$ ), federal law would characterize crimes over which tribal courts exercise jurisdiction as misdemeanors.

36 See Tim Vollman, Criminal Jurisdiction in Indian Country, 22 Kan. L. Rev. 387, 390 (1974); Clinton, supra note 30.

$37 \quad 25$ U.S.C. $\$ 3651$.

38. Bureau of Justice Statistics, U.S. Department of Justice, LaWrence A. Greenfield \& Steven K. Smith, American Indians and CRIMe (Feb. 1999). See also Contemporary Tribal Governments: Hearing on Impact of Supreme Court Rulings on Law Enforcement in Indian Country Before the Senate Comm. on Indian Affairs, 107th Cong. 10-12 (2002) [hereinafter Hearing] (statement of U.S. Attorney Thomas Heffelfinger and statement of Tracey Toulou, Director of Tribal Justice).

39 See, e.g., Dan K. Kahan, Reciprocity, Collective Action and Community Policing, 90 CAL. L. REv. 1513 (2002).

40 18 U.S.C. $\S 1153$ (providing for federal prosecution of murder, manslaughter, kidnapping, maiming, sex abuse, incest, assault with intent to commit murder, assault with a dangerous weapon, assault resulting in serious bodily injury, assault against an individual who has not attained the age of sixteen years, arson, burglary, robbery, and felony larceny).

41 The United States Department of Justice takes the position that it may prosecute any other federal criminal offense in which situs is not an element of the offense, such as narcotics offenses. See U.S. AtToRneys' OfFice, Criminal RESOURCE MANuAL 678.

42 Diane E. Murphy, Inside the United States Sentencing Commission: Federal Sentencing Policy in 2001 and Beyond, 87 lowa L. REv. 359, 362 (2002).

${ }_{43}$ See, e.g., U.S. Sentencing Comm'n, Supplementary Report, supra note 7 , at $41-43$.

44 See, e.g., Aaron Rappaport, Rationalizing the Commission; The Philosophical Premises of the U.S. Sentencing Guidelines, 52 EmoRY L.J. 557, 566-71 (2003). See also Paul J. Hofer \& Mark H. Allenbaugh, The Reason Behind the Rules: Finding and Using the Philosophy of the Federal Sentencing Guidelines, 40 Am. CRIM. L. Rev. 19, 51-53 (2003).

45 U.S.S.G., Criminal History, pt. A, introductory $\mathrm{cmt}$.

46 U.S. Sentencing COMmission, SUPplementary REPORT, supra note 7 , at 42.

47 For a sampling of reported cases involving such upward departures, see, e.g., United States v. Waugh, 207 F.3d 1098, 1102 (8th Cir. 2000); United States v. G.L., 143 F.3d 1248 (9th Cir. 1998); United States v. Juvenile PWM, 121 F.3d 328 (8th Cir. 1997) (reversed on other grounds); United States v. Drapeau, 110 F.3d 618 (8th Cir. 1997); United States v. Burke, 80 F.3d 314 (8th Cir. 1996); United States v. Claymore, 978 F.2d 421 (8th Cir. 1992).

48 See United States v. Juvenile Male WW, 322 F.3d 482, 485 \& n.4 (8th Cir. 2002); United States v. Juvenile JG, 139 F.3d 584,586 \& n.2 (8th Cir. 1998).

49 Williams v. Lee, 358 U.S. 217 (1959).

50 Michigan v. Wemigwans, No. 239736, 2003 WL 734257 (Mich. Ct. App. 2003); Montana v. Spotted Eagle, 71 P.3d 1239 (Mont. 2003); N.M. Stat. ANN. § 66.8.102(M); N.M. STAT. ANN. § 66-8-102(M); Wisconsin v. Schuman, 520 N.W.2d 107 (Wis. Ct. App. 1994) (applying state statute allowing use of tribal court convictions), rev. denied, 524 N.W.2d 142 (1994).

51 ARK. COde AnN. § 12.12.903(12)(A)(iii)(2002); GA. COdE Ann. $\S 42 \cdot 1-12$ (2002); IDAHO CODE $\S 18.8303$ (2002); IOWA CODE ANN. § 692A.2 (2002); James A. Billings \& Crystal L. Bulges, Comment, Maine's Sex Offender Registration and Notification Act: Wise or Wicked?, 52 ME. L. Rev. 175 (2002); Mo. CODE ANN., Criminal Procedure $\S 11.701(a)(4)(2002) ;$ MASS. GEN. LAWS ANN. Ch. $6 \S 178 \mathrm{C}$ (2002); MICH. COMP. LAWS ANN. $\S 28.722$ (2002); OHIO Rev. Code ANN. $\$ 2950.01$ (2002)

52 ARIz. ReV. Stat. § 13.3601.01 (2002).

53 Kansas, for example, does so in its burglary statute. KaN. STAT. ANN. § 21.4711 (2001).

${ }_{54}$ See U.S.S.G. $\S 4$ A1.2(i).

ss See United States v. Lopez, 514 U.S. 549 (1995); United States v. Morrison, 529 U.S. 598 (2000).

56 United States v. Kagama, 118 U.S. 375 (1886).

57 25 U.S.C. $\$ 1302(7)$.

58 See Federal Death Penalty Act of 1994, Pub. L. No. 103-322, Title VI, $\S 60002$ (a), 108 Stat. 1968 (1994) (codified at 18 U.S.C. § 3598). 